\title{
Comparative Evaluation of Lycopene Content and Some Chemical Properties of Commonly Consumed Brands of Tomato Paste in Port -Harcourt, South-South, Nigeria
}

\author{
Eke-Ejiofor J. \\ Department of Food Science and Technology, Rivers State University of Science and Technology, Port Harcourt, Nigeria
}

\section{Email address:}

joyekee@yahoo.co.uk

\section{To cite this article:}

Eke-Ejiofor J.. Comparative Evaluation of Lycopene Content and Some Chemical Properties of Commonly Consumed Brands of Tomato Paste in Port-Harcourt, South-South, Nigeria. Journal of Food and Nutrition Sciences. Vol. 3, No. 2, 2015, pp. 35-37. doi: $10.11648 / \mathrm{j} . j \mathrm{fns} .20150302 .12$

\begin{abstract}
A comparative evaluation of lycopene content and some chemical properties of commonly consumed brands of tomato paste were investigated. Six double concentrate tomato paste and a locally processed sample (freshly milled and boiled tomato used as control were reviewed. Chemical composition of the samples revealed that locally processed tomato was the least in total solids, $\mathrm{pH}$, viscosity and lycopene, with Gino tomato brand having the highest lycopene content. All brands of tomato paste showed a significant difference $(\mathrm{p}>0.05)$ in the chemical parameters. Proximate analysis showed that moisture content ranged from $69.00-84.85 \%$, while ash, protein and carbohydrate ranged from $1.11-2.80 \%, 2.95-4.87 \%$ and $7.91-$ $18.58 \%$ respectively, with the locally processed sample been the least in all cases. The findings in this study showed that there exist significant difference between tomato products in terms of lycopene and other chemical parameters as a result of processing and varietal differences.
\end{abstract}

Keywords: Tomato Paste, Evaluation, Lycopene, Chemical, Brand, Nigeria

\section{Introduction}

Tomato (Lycopersicom esculentum Mill) is a vegetable that occupy an important position in healthy daily family diet. It is grown extensively in home gardens and large farms for fresh consumption and commercial processing (Aditi et al 2011). It is consumed primarily for its color and the physical features it impacts on foods in addition to the provision of provitamin A. They are highly perishable and large quantities of tomato go as waste due to poor handling/storage facilities. As a summer fruit therefore, tomato must be preserved to be used throughout the annual cycle using concentration and heat treatment (Boumendjel et al 2011), giving rise to canning of tomato paste. Tomato, fresh or canned is primarily priced for its color which is due to the presence of the pigment lycopene. Lycopene is a terpen most abundant in the tomato fruit. It is a red pigment characterized by an acyclic symmetrical structure containing eleven conjugated double bonds and two unconjugated giving the molecule its red color (Nguyen et al., 1999). The determination of lycopene gives an indication of a quality criterion of tomato paste that is the color.
Lycopene is a member of the carotenoid family of phytochemicals, a hydrophobic molecule located within the tomato matix (Clinton 1998), a powerful antioxidant, with tomato as the richest source. Lycopene is the most prevalent carotenoid present in the human serum, accounting for roughly $50 \%$ of all plasma carotenoid content (Di Mascio et al 1989). Most of the dietary lycopene consumed by population in the Western World comes from tomato or their products (Khachik et al 2002 and Giovannucci 1999). It has been found to be beneficial in neutralizing harmful radicals, which are implicated in cancer, heart disease, macular degeneration and other age related illnesses (Agrawal et al 2000). The main quality parameters of tomato pastes perceived by consumers are color, consistency and flavor but less emphasis is laid on the nutritional and health benefits derived from consuming the processed tomato in terms of their lycopene content. The aim of the study was to compare the chemical properties of some tomato paste against the fresh unprocessed one with particular reference to the lycopene content. 


\section{Materials and Methods}

Materials: $70 \mathrm{~g}$ each of six different brands of tomato paste were purchased from a grocery shop in Port Harcourt. The brands of tomato paste were Gino, Pomo, Tasty tom, Sweet tomato, Frametta and De-rica. Fresh tomato seeds were also purchased from mill 3 market in Port Harcourt, milled and cooked to remove moisture to dryness and used for analysis.

Methods: Moisture content and ash were determined by the AOAC (1990) method. Viscosity measurement was done using a viscometer model $\mathrm{MDJ} / 8 \mathrm{~S}$ at $0.6 \mathrm{rpm}$ with spindle no 4 in duplicate. $\mathrm{pH}$ was determined using a $\mathrm{pH}$ meter model TS 625 Thomas scientific instrument. Total solid was obtained by difference (100- moisture content). Lycopene was determined by the method described by Ravelo-Perez et al (2000). Differences between means were assessed by analysis of variance and means separated by Duncan's Multiple range test according to the method of steel and Torrie (1980).

\section{Results and Discussion}

\subsection{Chemical Composition of Tomato Paste Samples}

Table 1 shows the chemical properties of the tomato paste. Total solids ranged from $15.15-30.99 \%$ with tasty- tom having the highest total solid and the locally processed sample having the least total solid. $\mathrm{pH}$ ranged from 3.99-4.38 with the locally processed sample having the least and sweet tomato brand the highest. The $\mathrm{pH}$ is a parameter indicating hygienic quality of tomato paste, its decline is interpreted as an improvement in conservation since they are classified as canned food plant at $\mathrm{pH}$ below 4.5, while Viscosity ranged from 510.40- 1074.35Pa.S with locally processed having the least and De-rica brand the highest. Viscosity is an important technological factor that is related to the content of substances insoluble in alcohol, protein, pectins and polysaccharides (Gallais et al 1992). Sobowale et al (2011) also reported that the viscosity of tomato products depend on fiber, protein, fat and total solids. Furthermore Hawbecker (1995) said that viscosity is the combined effect of liquid soluble material, insoluble in suspension that contribute to the overall consistency of tomato paste. Lycopene content ranged from $104.78-923.45 \mathrm{mg} / \mathrm{kg}$, with the locally processed having the least and Gino tomato paste having the highest. In agreement with the present findings, Nguyen and Schwartz (1998) reported that the availability of lycopene from tomato products is increased when these foods are processed at high temperature or packaged with oil. They also reported that mechanical treatment (homogenization) and heating enhance the release of lycopene from the tomato matrix and may explain the improved bioavailability seen with consumption of processed tomato products (cooked tomato, tomato paste). Furthermore, canned tomato and ketchup contain more lycopene than fresh tomato because cooking at high temperature breaks down cell walls, releasing and concentrating carotenoids There was a significant difference $(p>0.05)$ in lycopene content amongst the brands under review and between the tomato paste brands and the locally processed sample. This is also in agreement with the findings of (Rao and Agarwal 1998) who reported that significant differences exist between different tomato products in terms of lycopene release and its gastrointestinal absorption of the commonly consumed tomato products.

Table 1. Chemical properties (\%) of some tomato paste brands.

\begin{tabular}{|c|c|c|c|c|}
\hline Samples/ brands & Total solids\% & pH & Viscosity Pa.s & Lycopene $\mathrm{mg} / \mathrm{kg}$ \\
\hline TASTY TOM & $30.99^{\mathrm{a}}$ & $4.35^{\mathrm{a}}$ & $774.25^{b}$ & $489.14^{\mathrm{e}}$ \\
\hline POMO & $30.66^{\mathrm{a}}$ & $4.26^{\mathrm{a}}$ & $775.70^{b}$ & $903.00^{\mathrm{b}}$ \\
\hline GINO & $29.50^{\mathrm{b}}$ & $4.34^{\mathrm{a}}$ & $782.60^{\mathrm{b}}$ & $923.45^{\mathrm{a}}$ \\
\hline DE-RICA & $28.56^{\mathrm{c}}$ & $4.24^{\mathrm{a}}$ & $1074.35^{\mathrm{a}}$ & $442.35^{\mathrm{f}}$ \\
\hline SWEET TOMATO & $28.41^{\mathrm{c}}$ & $4 . .38^{\mathrm{a}}$ & $781.45^{b}$ & $599.46^{\mathrm{d}}$ \\
\hline FRAMETTA & $23.51^{\mathrm{c}}$ & $4.25^{\mathrm{a}}$ & $655.40^{c}$ & $687.32^{\mathrm{c}}$ \\
\hline
\end{tabular}

Table 2. Proximate compositon (\%) of some tomato paste brands.

\begin{tabular}{|c|c|c|c|c|}
\hline Samples/ brands & Moisture content $\%$ & Ash\% & CRUDE PROTEIN & TOTAL AVAILABLE CARBOHYDRATE(TAC) \\
\hline TASTY TOM & $69.00^{\mathrm{e}}$ & $2.51^{\mathrm{a}}$ & $4.63^{\mathrm{C}}$ & $18.58^{\mathrm{a}}$ \\
\hline POMO & $69.34^{\mathrm{e}}$ & $2.80^{\mathrm{a}}$ & $4.87^{\mathrm{a}}$ & $17.12^{\mathrm{b}}$ \\
\hline GINO & $70.47^{\mathrm{d}}$ & $2.70^{\mathrm{a}}$ & $3.31^{\mathrm{c}}$ & $16.34^{\mathrm{c}}$ \\
\hline DE-RICA & $71.40^{\mathrm{c}}$ & $2.81^{\mathrm{a}}$ & $4.82^{\mathrm{b}}$ & $13.07^{\mathrm{e}}$ \\
\hline SWEET TOMATO & $71.58^{\mathrm{c}}$ & $2.69^{\mathrm{a}}$ & $4 . .11^{\mathrm{f}}$ & $13.70^{\mathrm{d}}$ \\
\hline FRAMETTA & $76.40^{\mathrm{b}}$ & $2.50^{\mathrm{a}}$ & $4.15^{\mathrm{d}}$ & $12.35^{\mathrm{f}}$ \\
\hline LOCALLY PROCESSED & $84.85^{\mathrm{a}}$ & $1.11^{\mathrm{b}}$ & $2.95^{\mathrm{g}}$ & $7.91^{\mathrm{g}}$ \\
\hline
\end{tabular}

\subsection{Proximate Composition of Tomato Paste Samples}

Table 2 shows the proximate composition of the tomato brands. Moisture content ranged from 69.00-84.85\%, with tasty tom brand having the least and the control (locally processed sample) having the highest. In comparison with the pre-treated and canned brands, control sample showed higher final moisture even after dehydration. Increase in moisture showed a decrease in total solid. Ash ranged from 1.11$2.81 \%$ with control (locally processed tomato) having the least ash, while crude protein ranged from $2.95-4.87 \%$. In 
both ash and protein, the locally processed sample had the least value. There was no significant difference $(p<0.05)$ in ash among the tomato paste brands, but a significant difference $(p>0.05)$ between the brands and the locally processed sample. Total available carbohydrate (TCA) ranged from $7.91 \%$ - $18.58 \%$ with the locally processed sample as the least. Results in the present study showed that total available carbohydrate (TAC) decreased with an increase in moisture content. The protein level is a technological parameter, its variation does not affect the commercial quality products but affects the overall expression of refractive index expressed as brix (Boumendjel et al 2011).

\section{Conclusion}

Results of the present study have shown that all brands of commonly used canned tomato paste do not have the same quality in terms of lycopene, total solid, viscosity and other chemical parameters. Furthermore the study have also shown that lycopene content, moisture, ash, crude protein and total available carbohydrate improved with heat processing indicating better indices for storability.

\section{References}

[1] Aditi Gupta, Kawatra, A and Sehgal, S. (2011): PhysicalChemical properties and nutritional evaluation of newly developed tomato genotypes. African Journal of Food Science and Tech, vol 2(7) pp167-172.

[2] Agarwal, S and Rao, A.V.(2000): Tomato, lycopene and its role in human health and chronic disease. CMAJ 163(6), 739744.

[3] AOAC (1990): Association of Official Analytical Chemists, $15^{\text {th }}$ Editions. Washington. D.C
[4] Boumendjel, M , Perraya D (2008): Cederon multimedia du cours de conservation des denerees alimentaires. CDAOA Version $\quad 1.11 \quad$ cours ligne (http;//cdaoa. Djamiatic.net).copyright@ office national des Droit

[5] Clinton, S.K. (1998): Chemistry, biology and implimentations for human health and disease. Nut Rev 56(2 pt 1): 36-51

[6] Di Mascio, P; Kaiser, S and Sies, H. (1989): Lycopene as the most efficient biological carotenoid singlet oxygen quencher. Biochemistry and Biophysics vol 274 (2): 532-538.

[7] Gallais A and Bannerot H (1992): Amelioration des especes vegetales cultivees: Objectifs et criteres de selection-INRA pp 379-391.

[8] Giovannucci, E. (1999): Tomatoes, tmato based products, lycopene and cancer review of the epidemiologic literature. $J$ Natl Cancer Inst 91(4): 317-331

[9] Hawbecker D.E (1995) ; Microbiology, packaging, HACCP and Ingredients. Plant Quality Control. Comstock Michigan Fruits Div; 7, 261-283.

[10] Khachik, F. Carvalho, L and Berristein, P.S. (2002): Chemistry, distribution and metabolism of tomato carotenoids and their impact on human health. Exp Biol Med (Maywood) 227(10): 845-851

[11] Ravelo-perez Lidia Maria, Javier Hernandez-Borges, Miguel Angel Rodriguez-Delgado(2007): 'Spectrophotometric Analysis of lycopen in Tomato and Watermelons" The chemical Educator vol 13. No 1.

[12] Nguyen, M.L and Schwartz, S.J. (1998): Lycopene stability during food processing. Proc Soc Exp Biol Med 281(2): 101105

[13] Rao, A.V. and Agarwal, S. (1998): Bioavailability and invivo antioxidant properties of lycopene from tomato products and their possible role in the prevention of cancer Nutr Cancer 31(3): 199-203.

[14] Steel, R. G. and Torrie, J. H. (1980): Principles and Procedures of Statistics. A biomedical approach, $2^{\text {nd }}$ ed. M. C. Graw-Hill, Internationial. Auckland, P. 50-110. 